\title{
The use of morphometric analysis to predict the swimming efficiency of two Neotropical long-distance migratory species in fish passage
}

\author{
Lucileine de Assumpção ${ }^{1}$, Maristela Cavicchioli Makrakis ${ }^{1}$, Sergio Makrakis ${ }^{1}$, \\ Ricardo Luiz Wagner ${ }^{1}$, Patrícia Sarai da Silva ${ }^{1}$, Ariane Furtado de Lima ${ }^{1}$ and \\ Elaine Antoniassi Luiz Kashiwaqui ${ }^{2}$
}

This study investigated the external body morphology (based on morphometric data) and the swimming efficiency in fish passages (based on the ascent time in a fish ladder) of two Neotropical long-distance migratory species. The fish were collected in the fish ladder of the Porto Primavera Hydroelectric Power Plant (known as Engenheiro Sergio Motta), upper Paraná River, Brazil. The species differ in several morphometric ratios related to swimming performance. Prochilodus lineatus exhibited a higher muscle ratio and caudal fin length ratio. However, Leporinus elongatus showed higher values for the fineness ratio, a higher length from snout to pectoral fin base ratio, and a higher caudal peduncle depth factor. Although both species show good swimming performance, the characteristics listed above may enable $L$. elongatus to apply greater power and propulsion, allowing it to reach a high swimming speed and to exhibit greater efficiency than $P$. lineatus. Leporinus elongatus moves faster than P. lineatus and has a lower mean ascent time (1.39 hours) than P. lineatus ( 3.76 hours). Prochilodus lineatus would require a somewhat longer time to pass through the fish ladder.

Este estudo investigou a relação entre a morfologia externa do corpo (baseado em dados morfométricos) e eficiência de natação em passagem para peixes (baseado no tempo de ascensão em uma escada para peixes) de duas espécies neotropicais migradoras de longas distâncias. Os peixes foram coletados na escada para peixes da Usina Hidrelétrica de Porto Primavera (conhecida como Engenheiro Sérgio Motta), alto Rio Paraná, Brasil. As espécies diferem em algumas razões morfométricas referentes ao desempenho de natação: Prochilodus lineatus apresentou valores mais elevados para razão muscular e razão do comprimento da nadadeira caudal. No entanto, Leporinus elongatus apresentou valores mais elevados para razão fineza, para razão do comprimento do focinho à base da nadadeira peitoral e para fator de largura do pedúnculo caudal. Embora ambas as espécies tenham um bom desempenho natatório, essas características podem permitir a L. elongatus aplicar uma maior potência e propulsão, permitindo atingir velocidades de natação elevadas e apresentar uma melhor eficiência em relação a $P$. Lineatus. Leporinus elongatus movimenta-se mais rápido, com um tempo médio de ascensão (1,39 horas) inferior ao de $P$. lineatus (3,76 horas), que requer um tempo um pouco maior para passar através da escada para peixes.

Key words: Fineness ratio, Fish swimming, Fishway, Morphology, Swimming performance.

\section{Introduction}

Most of the major rivers in South America have been severely segmented by dams, and this is particularly the case for the Paraná River Basin. The management actions taken to minimize the impacts of dams on migratory species in South American river systems include the construction of fish passages, fishery control and stocking (Agostinho et al., 2008; Pompeu et al., 2011). Fish passage systems, especially fish ladders, have been deployed in hydropower projects, and the challenge that they must meet is to mitigate the effects of the blockage of the river by the dam in a way that provides passage routes that are both safe and effective (Castro-Santos $\&$ Haro, 2010) for Neotropical migratory species.

${ }^{1}$ Universidade Estadual do Oeste do Paraná (UNIOESTE), Pós-Graduação em Recursos Pesqueiros e Engenharia de Pesca, Grupo de Pesquisas em Tecnologia de Produção e Conservação de Recursos Pesqueiros e Hídricos (GETECH). Rua da Faculdade, 645, Jardim Santa Maria.85903-000 Toledo, PR, Brazil. lucileinea@hotmail.com (LA), mmakrakis@terra.com.br (MCM), makrakis@terra.com.br(SM), ricabatata@hotmail.com(RLW), pathypesca@hotmail.com (PSS)

${ }^{2}$ Universidade Estadual de Mato Grosso do Sul, Grupo de Estudos em Ciências Ambientais e Educação (GEAMBE). BR-163, Km 20.2, Mundo Novo, Mato Grosso do Sul. PNPD - PREP/CAPES, GETECH/UNIOESTE, Rua da Faculdade, 645, Jardim Santa Maria. 85903000 Toledo, Paraná, Brazil. elainealk@yahoo.com.br 
The fish of the Paraná River Basin show diverse migratory patterns (Makrakis et al., 2012), and fish species could react differently to obstacles that hinder migration. Despite the importance of the characteristics of Neotropical migratory species, including their behavior, morphology, physiology, and capacities, these characteristics have been ignored in formulating design criteria for fish passages in Brazil. The factor of greatest concern in fish passage design is the swimming performance of migratory species (Beach, 1984; Santos et al., 2008). This factor is considered one of the primary determinants of survival because it defines the ability of the fish to conduct activities in which swimming is involved (Beamish, 1978; Plaut, 2001). Swimming performance can be influenced by the locomotion pattern, body size, shape, physiology, temperature and behavior (Beamish, 1978; Videler \& Wardle, 1991; Hammer, 1995 ) and can limit the use of the habitat by a species (Sambilay, 1990; Bandyopadhyay et al., 1997; Gerstner, 1999).

The relationship between swimming performance and body morphology is an appropriate topic to consider in evaluating fish functional anatomy because performance depends on the drag force and on propulsion (Videler, 1993). This relationship influences the capacity of the fish to maintain its position in flowing water. In addition, this topic is relevant to the acquisition of food and the avoidance of predators (Videler, 1993), as well as to migration success (Fisher \& Bellwood, 2003). Many morphological traits of the body of a fish are considered important for defining the swimming capacity, including the aspect and muscle ratios (Sambilay, 1990; Fisher et al., 2000), caudal peduncle depth factor (Webb \& Weihs, 1986), propulsive ratio (Fisher et al., 2000), caudal fin length ratio (Nanami, 2007), and fineness ratio (Bainbridge, 1960; Webb, 1975; Blake, 1983; Scarnecchia, 1988). The body shape and the fin size can accurately indicate the behavior, swimming mode and habitat preferences of fish (Keast \& Webb, 1966; Webb, 1984), providing a more accurate understanding of the fish's body shape and its structure and functions (Winemiller, 1991).

Several studies have explored the relationship among habitat selection, morphology and swimming capacity (e.g., Ohlberger et al., 2006; Fisher \& Hogan, 2007; Nanami, 2007; Aedo, 2008), and some have correlated habitat use with morphological characters for Neotropical fish species. However, studies of the swimming performance of these species have been conducted only recently, and this information is available for two migratory species: Leporinus reinhardti (Characidae) and Pimelodus maculatus (Pimelodidae) (Santos et al., 2007; 2008). Furthermore, information on the functional relationships associated with morphology and with behavior in fish passages remains scarce.

Given that morphological characteristics can be reliably used to predict fish swimming performance, this study aims to investigate the external body morphology (based on morphometric data) and swimming efficiency in fish passages (based on the ascent time in a fish ladder) of two Neotropical long-distance migratory species, Leporinus elongatus Valenciennes, 1850, known as piapara, and Prochilodus lineatus (Valenciennes, 1837), known as curimbata. These species are long-distance migrants in the Paraná River Basin (Agostinho et al., 2007; Makrakis et al., 2012), moving upstream in the Paraná River to reproduce (Agostinho et al., 2003). Both species are highly important for fisheries. They have been observed in the fish passage systems along the Paraná River, including the fish ladder at the Porto Primavera Hydroelectric Power Plant (Makrakis et al., 2007a) and Piracema Canal, a lateral channel at Itaipu Dam (Makrakis et al., 2007b). Progress in the knowledge of Neotropical migratory species may facilitate research on swimming performance and on the planning of future fish passage systems.

\section{Material and Methods}

\section{Study area}

This study was conducted at the fish ladder (Fig. 1) of the Porto Primavera Hydroelectric Power Plant, also known as Engenheiro Sérgio Motta, belonging to Companhia Energética de São Paulo (CESP). The site is located on the upper Paraná River on the border between São Paulo and Mato Grosso do Sul States, Brazil. The fish ladder (weir and orifice type) is located on the left side of the dam and is $520 \mathrm{~m}$ long. It consists of fifty concrete weirs forming pools $5 \mathrm{~m}$ wide $\mathrm{x} 2 \mathrm{~m}$ high. These structures aid the fish to reach the reservoir (for details see Makrakis et al., 2007a).

\section{Morphological characterization}

The specimens (40 fish of each species) of Leporinus elongatus and Prochilodus lineatus (Fig. 2) were caught between November 2007 and October 2009 in the fish ladder with seine and casting nets. The total length of the specimens ranged from 40.1 to $54.5 \mathrm{~cm}$ for L. elongatus and from 42.7 to $53.7 \mathrm{~cm}$ for $P$. lineatus.

The fish caught were anesthetized (benzocaine- $75 \mathrm{mg} / \mathrm{l}$ ). Each fish was photographed in a lateral position with a Sony Cybershot DSC-H50 camera with 9.1 megapixels. Data for morphometric measurements were obtained from the digital images of the fish according to Fisher \& Hogan (2007). These measurements were taken to the nearest $0.1 \mathrm{~mm}$ with UTHSCSA Image Tool 3.0 software. The morphometric variables used are shown and defined in Fig. 3.

The total (TL) and standard length (SL) and body maximum width (BMW, measured at the widest region) were also measured to the nearest $0.1 \mathrm{~mm}$ with a digital caliper. This procedure was performed for TL and SL to obtain the true values for use in calibrating the unit of measurement $(\mathrm{mm})$ for the images obtained from the software. The BMW was measured to calculate the fineness ratio because this width measurement could not be obtained from the images with the software.

The fish were released in the fish ladder after the completion of the procedures.

A total of 13 morphometric measurements (expressed in $\mathrm{mm}$ ) were analyzed (Fig. 3; Table 1). These measurements included lengths (total length, standard length, snout length to the base of pectoral fin, and caudal fin length), widths (maximum body width), heights (maximum body height, caudal 


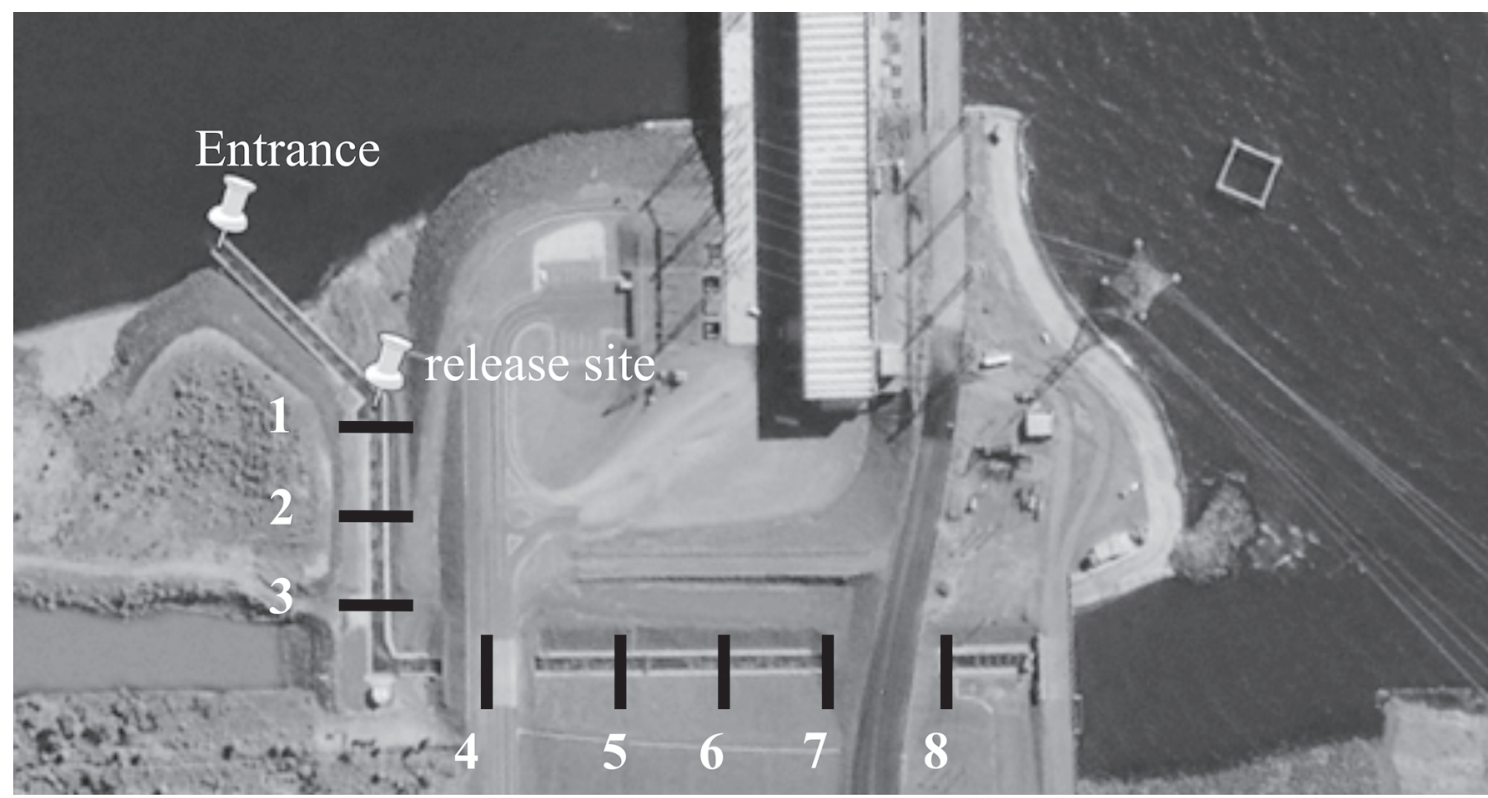

Fig. 1. Distribution of the antennas (1 to 8) along the fish ladder of the Porto Primavera Hydroelectric Power Plant, upper Paraná River, Brazil. Source: “Fish ladder”. 22²9’02.82”S and 5257’28.94”W. Google Earth. June 28, 2002. February 6, 2012.

peduncle height and caudal fin height) and areas (body area, propulsion area, muscle area, caudal fin area, and pectoral fin area). These measurements were used to obtain the morphometric ratios (Table 2) that are considered potentially important for describing the swimming performance of fish (Fisher \& Hogan, 2007; Nanami, 2007).

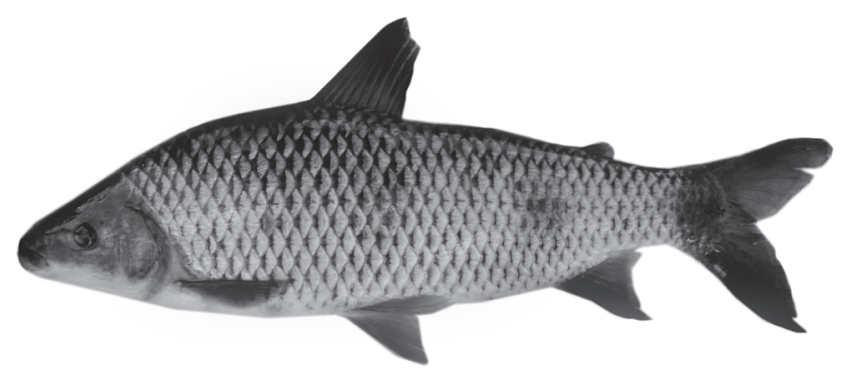

a

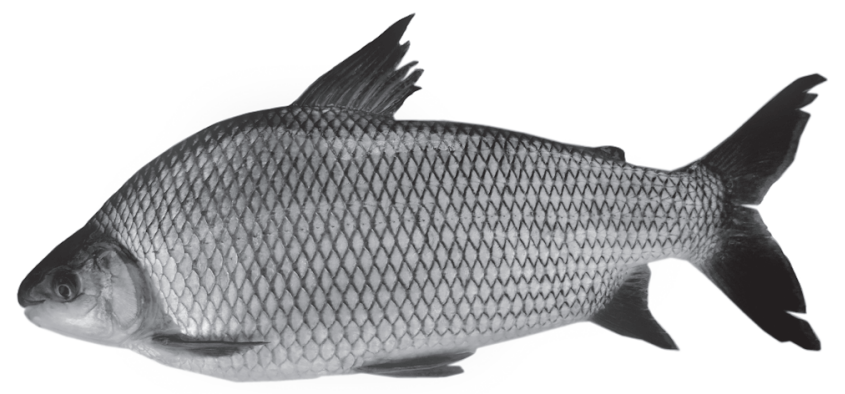

b

Fig. 2. Photographs of Leporinus elongatus (a) and Prochilodus lineatus (b) collected in the fish ladder.

\section{Ascent time}

To analyze the time spent ascending the fish ladder by the two species studied, eight antennas with dimensions of $1.5 \times 3.0$ $\mathrm{m}$ were installed. The antennas were constructed with electric wires of $4 \mathrm{~mm}^{2}$ in size, inserted into polyvinyl chloride tubes, and attached to the wall of the fish ladder with a wooden frame. The first antenna (antenna 1) was installed $100 \mathrm{~m}$ upstream from the entrance to the ladder, just upstream from the first resting pool. The last (eighth) antenna was positioned $50 \mathrm{~m}$ downstream from the exit from the ladder. The other antennas were distributed equidistantly along the fish ladder (Fig. 1). The Radio Frequency Identification (RFID) system was used in the fish ladder.

Leporinus elongatus and Prochilodus lineatus were caught along the fish ladder between September 2009 to January 2010 with seine and cast nets, anesthetized using benzocaine, and marked with PIT (Passive Integrated Transponder) tags of $32 \mathrm{~mm}$. The tag was implanted through a small opening in the peritoneal cavity. After marking, the fish were placed in a cage located near the release site for recovery (20 minutes). The fish were released $85 \mathrm{~m}$ upstream from the entrance to the fish ladder (Fig. 1).

A total of 139 adult fish were tagged (30 specimens of $L$. elongatus and 109 specimens of Prochilodus lineatus). The total length of the specimens ranged from 40.2 to $52.4 \mathrm{~cm}$ for L. elongatus and from 33.5 to $58.0 \mathrm{~cm}$ for P. lineatus. Of the 139 tagged fish, 41 were recorded (RFID system) by all antennas during upward movements during the monitoring period (September 2009 to April 2010). These fish included nine $(30 \%)$ L. elongatus and $32(29 \%)$ P. lineatus. It is probable that most of the tagged fish migrated downstream after tagging or were not detected by the RFID system. 

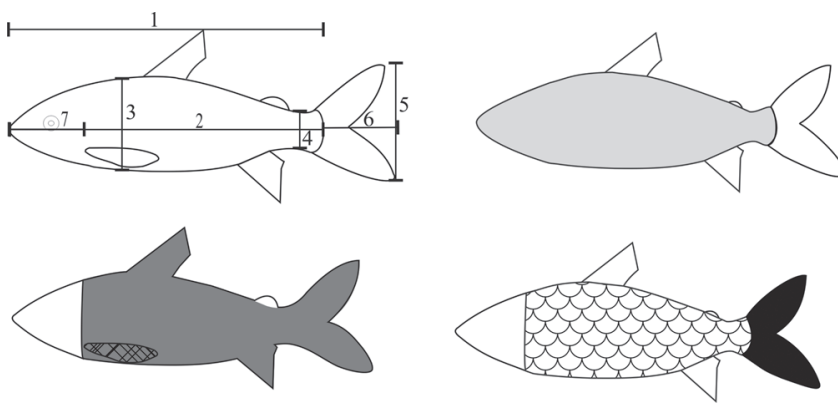

Fig 3. Morphological measurements (1-7) and areas related to swimming performance for Leporinus elongatus and Prochilodus lineatus: 1) standard length (SL), 2) total length (TL), 3) body maximum height $(\mathrm{BMH}), 4)$ caudal peduncle height $(\mathrm{CPdH}), 5)$ caudal fin height $(\mathrm{CFH}), 6$ ) caudal fin length (CFL), and 7) length from snout to pectoral fin base (LNPtFB). Body area - BA (gray), propulsive area - PA (dark gray), muscle area - MA (fish scale), caudal fin area - CFA (black), and pectoral fin area - PtFA (crosshatching).

\section{Data analysis}

The data on the total and standard lengths were investigated to determine whether the body size in the group used for the morphometric measurements differed from the body size in the group marked with the PIT tags (including the fish showing upward movement). This comparison was used to increase the robustness of the subsequent analysis. These variables were tested with a one-way ANOVA.

A Principal Component Analysis (PCA) of the morphometric ratio values (log-transformed) was conducted with PC-ORD v.4.01 software (McCune \& Mefford, 1999). The PCA was applied to investigate the morphological patterns shown by the species. The selection of axes for interpretation was performed with the Broken-Stick method (Jackson, 1993). An ANOVA was applied to the scores on the retained axis from the PCA to evaluate significant differences between species in the morphometric ratios.
The efficiency of swimming during the ascent of the fish ladder was evaluated based on the time spent in each section (antennas) and in the fish ladder (total time) for each species. A Kruskal-Wallis one-way analysis (for non-normal data) was used to examine the differences in the time taken by each species to ascend different sections of the fish ladder. A MannWhitney rank sum test (for non-normal data) was used to examine the mean time taken by each species to ascend the fish ladder.

Statistica 7.0 software was used for the ANOVA, KruskalWallis one-way and Mann-Whitney tests. The level of significance was $\mathrm{p}<0.05$.

\section{Results}

\section{Morphological characterization}

The Principal Component Analysis (PCA) applied to evaluate the morphometric ratios between Leporinus elongatus and Prochilodus lineatus yielded two axes. These axes explained $66.66 \%$ of the variability of the data set. According to the Broken-Stick method (Table 3), only the first axis (PC1) was significant, explaining $47.77 \%$ of the total variability. The morphometric variables that contributed positively to the formation of the spatial gradient of the PC1 scores were the fineness ratio (FR) (0.884), the caudal peduncle depth factor (CPdDF) (0.777), and the length from snout to pectoral fin base ratio (LNPtFBR) (0.889). The variables with negative coefficient values were the muscle ratio (MR) (-0.773) and the caudal fin length ratio (CFLR) (-0.771) (Table 3$)$.

The distribution of PCA scores (Fig. 4) showed that the two species differ in several morphometric ratios associated with swimming performance. Prochilodus lineatus exhibited higher values of the muscle ratio (MR) and the caudal fin length ratio (CFLR). However, the scores for Leporinus elongatus were positive and showed higher values for the fineness ratio (FR), an indication of the thinner body of this species; a higher length from snout to pectoral fin base ratio (LNPtFBR); and a higher caudal peduncle depth factor (CPdDF), an indication that the height of the caudal peduncle

Table 1. Description of the morphological measurements.

\begin{tabular}{|c|c|c|}
\hline Morphological measurements (mm) & Acronym & Description \\
\hline Total length & TL & Distance between the tip of the snout and the end of the caudal fin. \\
\hline Standard length & SL & Distance between the tip of the snout and the end of the caudal peduncle. \\
\hline Length from snout to pectoral fin base & LNPtFB & Distance from the snout to the pectoral fin base. \\
\hline Caudal fin length & CFL & Distance from the end of the caudal peduncle to its posterior extremity. \\
\hline Body maximum width & BMW & Greatest horizontal distance perpendicular to the longitudinal axis of the body. \\
\hline Body maximum height & $\mathrm{BMH}$ & Greatest ventral-dorsal distance on the longitudinal axis of the body. \\
\hline Caudal peduncle height & $\mathrm{CPdH}$ & Smaller caudal peduncle depth. \\
\hline Caudal fin height & $\mathrm{CFH}$ & Greatest vertical distance perpendicular to the length axis. \\
\hline Body area & BA & Area in lateral view, excluding the fins. \\
\hline Propulsive area & PA & $\begin{array}{l}\text { Area including the fins (naturally fully extended) but excluding the head and gut region where } \\
\text { they are inflexible or lack overlying muscle and cannot be used for propulsion. }\end{array}$ \\
\hline Muscle area & MA & Area excluding the fins, head and gut region. \\
\hline Caudal fin area & CFA & Area with the caudal fin naturally fully extended. \\
\hline Pectoral fin area & PtFA & Area with the pectoral fin naturally fully extended. \\
\hline
\end{tabular}


Table 2. Morphometric ratios calculated for Leporinus elongatus and Prochilodus lineatus.

\begin{tabular}{|c|c|c|c|c|}
\hline Morphometric ratios & Acronym & Calculation & Description & Reference \\
\hline Muscle ratio & (MR) & $\mathrm{MA} / \mathrm{BA}$ & $\begin{array}{l}\text { The ratio of the muscle area of the fish to the } \\
\text { total body area }\end{array}$ & Fisher et al. (2000) \\
\hline Propulsion ratio & (PR) & $\mathrm{PA} / \mathrm{BA}$ & $\begin{array}{c}\text { The ratio of the propulsion area to the total body } \\
\text { area }\end{array}$ & Fisher et al. (2000) \\
\hline Fineness ratio & (FR) & $\mathrm{SL} /[(\mathrm{BMW}+\mathrm{BMH}) / 2]$ & $\begin{array}{l}\text { Length divided by the average of the body width } \\
\text { and the body depth }\end{array}$ & Bainbridge (1960) \\
\hline Aspect ratio & (AR) & $\mathrm{CFH} / \mathrm{CFA}^{1 / 2}$ & $\begin{array}{c}\text { Caudal fin height divided by the square root of } \\
\text { the caudal fin area }\end{array}$ & Sambilay (1990) \\
\hline Caudal fin length ratio & (CFLI & $\mathrm{CFL} / \mathrm{TL}$ & Caudal fin length divided by total length & Nanar \\
\hline Caudal peduncle depth factor & $(\mathrm{CPdDF})$ & $\mathrm{CPdH} / \mathrm{BMH}$ & Caudal peduncle depth divided by body depth & Webb \& Weihs (1986) \\
\hline Pectoral fin length ratio & (PtFLR) & $\mathrm{PtFA} / \mathrm{BA}$ & Pectoral fin area divided by body area & Gatz (1979) \\
\hline $\begin{array}{l}\text { Length from snout to pectoral } \\
\text { fin base ratio }\end{array}$ & (LNPtFBR) & $\mathrm{LNPtFB} / \mathrm{TL}$ & $\begin{array}{l}\text { Length from snout to pectoral fin base divided by } \\
\text { total length }\end{array}$ & Nanami (2007) \\
\hline
\end{tabular}

of this species is lower. The scores on the axis (PC1) retained in the Principal Component Analysis also showed that the morphometric ratios of $P$. lineatus differed significantly from those of L. elongatus (ANOVA, $\mathrm{n}=80, \mathrm{~F}_{(1,78)}=415.08, \mathrm{p}<$ $0.001)$.

\section{Ascent time}

The data on total length (TL) and standard length (SL) from individuals marked with the Pit tags (nine specimens of Leporinus elongatus and 32 of Prochilodus lineatus) and from the individuals measured morphometrically ( 40 specimens of each species) showed no significant differences between groups (one-way ANOVA) (TL: $\mathrm{F}_{(1,39)}=1.3496, \mathrm{p}=0.25 ; \mathrm{SL}: \mathrm{F}$ $(1,39)=2.7883, \mathrm{p}=0.10)$. These results indicated that the two groups (the tagged and morphometrically measured fish) did not differ in size.

A Kruskal-Wallis test showed significant differences between the species in the times taken to ascend different sections of the fish ladder: antennas 1-2 $\left(\mathrm{KW}-\mathrm{H}_{(1,41)}=6.1915, \mathrm{p}<0.01\right), 2-3(\mathrm{KW}-$ $\left.\mathrm{H}_{(1,41)}=5.4325, \mathrm{p}<0.02\right)$, and 7-8 $\left(\mathrm{KW}-\mathrm{H}_{(1,41)}=7.8581, \mathrm{p}<0.01\right)$ (Fig. 5). However, no significant differences between the species were detected in the time taken in the remaining sections: antennas 3-4 $\left(\mathrm{KW}-\mathrm{H}_{(1,41)}=0.0089, \mathrm{p}=0.92\right), 4-5\left(\mathrm{KW}-\mathrm{H}_{(1,41)}=\right.$ $3.8135, \mathrm{p}=0.05), 5-6\left(\mathrm{KW}-\mathrm{H}_{(1,41)}=0.8929, \mathrm{p}=0.34\right)$, and 6-7 (KW-
$\left.\mathrm{H}_{(1,41)}=2.5804, \mathrm{p}=0.11\right)$ (Fig. 5). For both species, a longer time was spent in the section corresponding to antennas 3-4.

The ascent times of the two species differed significantly, as shown by a Mann-Whitney rank sum test $(\mathrm{Z}=2.87, \mathrm{p}=$ 0.004 ). Leporinus elongatus had a shorter ascent time (mean of 1.39 hours) than Prochilodus lineatus (mean of 3.76 hours) (rank sum test $=30$ and 75 , respectively).

\section{Discussion}

This study identified several aspects of external body morphology that are important for swimming efficiency in two long-distance migratory fish species. Although both species studied, Leporinus elongatus and Prochilodus lineatus, show a hydrodynamic body shape and a good swimming performance, they differ in several morphometric traits related to swimming performance. Leporinus elongatus, with a greater caudal peduncle depth factor, a greater length from snout to the pectoral fin base ratio and a greater fineness ratio, has greater swimming efficiency and moved more rapidly through the fish ladder than P. lineatus, in which the muscle ratio and caudal fin length ratio are greater.

The thinner caudal peduncle in L. elongatus can produce a decrease in the waves of turbulence caused by the movement

Table 3. Eigenvalues of the Principal Components Analysis (PCA) for morphometric ratios values $(\mathrm{PC} 1=\mathrm{Axis} 1, \mathrm{PC} 2=\mathrm{Axis} 2)$, and mean values of morphometric ratios for Leporinus elongatus (LE) and Prochilodus lineatus (PL). The variables with high eigenvalues are indicated in bold.

\begin{tabular}{|c|c|c|c|c|}
\hline \multirow{2}{*}{ Eigenvalues/morphometric ratios } & \multicolumn{2}{|c|}{ Mean morphometric ratios } & \multirow{2}{*}{ PC1 } & \multirow{2}{*}{ PC2 } \\
\hline & LE & $\mathrm{PL}$ & & \\
\hline$\overline{\text { Eigenvalue }}$ & & & 3.822 & 1.511 \\
\hline Eigenvalue - Broken-Stick & & & 2.718 & 1.718 \\
\hline$\%$ of variability explained & & & 47.77 & 18.89 \\
\hline Muscle ratio (MR) & 0.860 & 0.887 & -0.3952 & -0.3103 \\
\hline Caudal fin length ratio (CFLR) & 0.174 & 0.202 & -0.3943 & -0.2154 \\
\hline Propulsion ratio (PR) & 1.091 & 1.109 & -0.255 & -0.5888 \\
\hline Aspect ratio (AR) & 2.062 & 2.151 & -0.1222 & 0.2569 \\
\hline Pectoral fin length ratio (PtFLR) & 0.031 & 0.027 & 0.1979 & -0.6002 \\
\hline Caudal peduncle depth factor (CPdDF) & 0.397 & 0.367 & 0.3974 & -0.2245 \\
\hline Fineness ratio (FR) & 4.679 & 4.018 & 0.452 & -0.1289 \\
\hline Length from snout to pectoral fin base ratio (LNPtFBR) & 0.193 & 0.153 & 0.455 & -0.132 \\
\hline
\end{tabular}




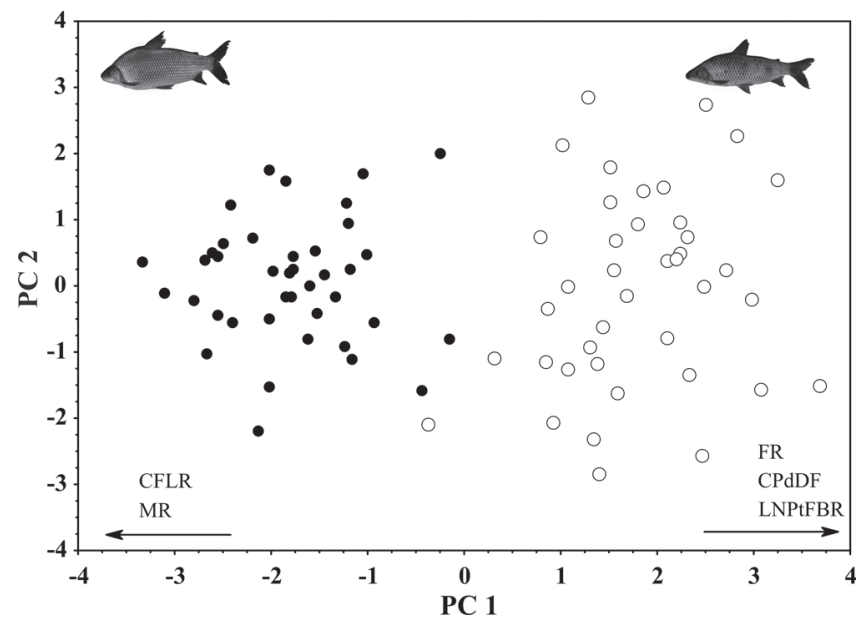

Fig. 4. Individual scores from Principal Component Analysis (PCA) showing the sources of interspecific variability for Leporinus elongatus (white circle) and Prochilodus lineatus (black circle). $\mathrm{CFLR}=$ caudal fin length ratio; $\mathrm{MR}=$ muscle ratio; $\mathrm{FR}=$ fineness ratio $\mathrm{CPdDF}=$ caudal peduncle depth factor, and $\mathrm{LNPtFBR}=$ length from snout to pectoral fin base ratio.

of the anterior region of the body. This feature is associated with a greater caudal fin height, with the upper and lower extremities of the fin outside the zone of turbulence, and it allows the fish to apply more power and propulsion (Breda $e t$ al., 2005). However, the greater muscle ratio (MR) demonstrated for $P$. lineatus indicates that it may be more resistant to moving water, remaining in position at high water velocities. A greater muscle ratio also enables this species to sustain itself in rapid and turbulent waters. The associated energy expenditure is lower because the body is larger and higher. As the body size increases, the volume corresponding to the muscle mass also increases, allowing the fish to reach higher speeds during prolonged swimming (Beamish, 1978).

Although the propulsion ratio (PR) is related to the muscle mass of the fish (Fisher \& Hogan, 2007), this ratio was similar between species. Ohlberger et al. (2006) verified that Mugil cephalus Linnaeus, 1758 has better swimming ability due to its morphological characteristics (greater muscle and propulsion areas), suggesting that superior swimming capacity is based primarily on the development of muscles and other traits related to fish locomotion. Studies by Fisher et al. (2000) showed similar results for the three reef fish species Pomacentrus amboinensis Bleeker, 1868, Sphaeramia nematoptera (Bleeker, 1856) and Amphiprion melanopus Bleeker, 1852. In these species, the critical swimming speed was positively correlated with the propulsion area.

A streamlined body is an elongated and fusiform shape that minimizes drag while maximizing volume, and the fineness ratio is the most common and straightforward method of measuring this characteristic (Langerhans \& Reznick, 2010). Fineness ratios between 2 and 6 result in a decrease of the drag produced by the fish, and species with a fineness ratio of 4.5 have an optimum

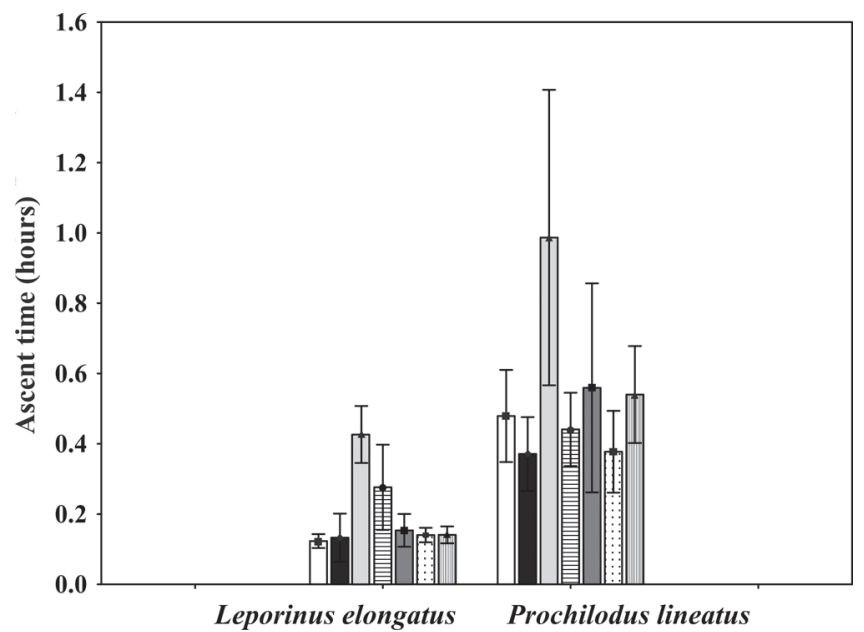

Fig. 5. Mean ascent time (hours) \pm standard error for Leporinus elongatus and Prochilodus lineatus relative to antennas in the fish ladder. Bars: white (Antennas 1-2), black (2-3), gray (3-4), horizontal line (4-5), dark gray (5-6), dashed line (6-7), vertical line (7-8).

swimming capacity (Webb, 1975; Blake, 1983; Langerhans \& Reznick, 2010). The streamlined body and mean fineness ratio of 4.6 observed for $L$. elongatus may indicate a greatly superior swimming performance. Studies conducted with Cyprinus carpio Linnaeus, 1758 and Rutilus rutilus (Linnaeus, 1758) to evaluate differences in swimming capacity demonstrated a fineness ratio lower than 4.5 for $C$. carpio, whereas $R$. rutilus showed greater values. These results showed that the hydrodynamic body shape of $R$. rutilus was appropriate to facilitate swimming performance (Ohlberger et al., 2006). However, according to Castro-Santos (2005), all fish can optimize their swimming velocity, although certain species are better able to do so.

The caudal peduncle depth factor (CPdDF) is strongly related to the swimming speed (Fisher \& Hogan, 2007), and it is an important determinant of the swimming ability of the fish. This factor was also essential for differentiating $L$. elongatus and $P$. lineatus: L. elongatus exhibited a higher mean CPdDF (0.39) than $P$. lineatus (0.36). Similar values were found for Leporinus obtusidens (Valenciennes, 1847) and P. lineatus (0.40 and 0.37, respectively) by Carneiro (2003). Fish that show a superior ability to accelerate have a deep caudal peduncle (Webb, 1994). In contrast, a narrow caudal peduncle is typical of thunniform fish, which use an axially oscillating caudal fin to generate thrust for cruising at high speed (Webb, 1984; Webb \& Weihs, 1986).

According to Gosline (1971), propulsive force is related to caudal peduncle width. A thin caudal peduncle with a higher caudal fin overcomes the waves induced by the movement of the anterior region of the body, promoting a higher propulsive force (Aleev, 1969). In addition, the caudal peduncle and the frequency of tail flapping are important for producing a jet of high propulsive efficiency (Triantaffylou \& Triantaffylou, 1995). A greater caudal fin 
area, as observed in the longer caudal fin of $P$. lineatus, is important for acceleration (Balon et al., 1986), and the caudal fin length ratio is significantly related to swimming performance. This ratio has important consequences for thrust and for drag reduction (Videler, 1993).

The length from snout to pectoral fin base ratio differed between the species studied. In Leporinus elongatus, the pectoral fins are located closer to the center of gravity of the fish's body, indicating that the fish can easily turn its body (Nanami, 2007) and has a greater positioning ability. In contrast, a lower value of this ratio indicates that the axis for turning is located farther from the center of gravity, resulting in greater drag during turning (Nanami, 2007). A high pectoral fin length ratio (PtFLR) is associated with high swimming speed (Breda $e t$ al., 2005), as shown by the narrow and long fins of large migratory fish (Keast \& Webb, 1966). Nevertheless, this morphological ratio associated with fish locomotion was similar for the two species studied.

Several morphometric ratios differ between the species studied. In addition, the species exhibit different swimming efficiency. Leporinus elongatus is faster than Prochilodus lineatus; it had a lower mean ascent time (1.39 hours) than $P$. lineatus (3.76 hours), which required a longer time to pass through the fish ladder. According to Santos et al. (2007), the swimming capacity of the piau (Leporinus reinhardti) explained the success of this genus in ascending fishways in Brazil. It is possible that the swimming capacity of this genus is greater than that of other migratory characiformes.

Despite the difference in the time taken to ascend the fish ladder, both species Leporinus elongatus and Prochilodus lineatus moved relatively more rapidly in the section between antennas $1-2$ and 2-3, showing that more rapid swimming is required to pass through this section of the fish ladder. The section between antennas 3-4 is the longest section of the fish ladder. The two species spent a longer time in this section because it is a resting pool. The maximum possible ascent distance through fishways is governed by the swim speed-fatigue time relationship (Bainbridge, 1960). Data on this relationship have been used extensively to determine the location and size of resting pools within fishways (Beamish, 1978). Castro-Santos (2005) stated that any recommendations for fishway designs based on the swim speed-fatigue time relationship should therefore recognize the expected variability around the optimum and the costs of such variability in terms of the ascent distance if predictions of passage success are necessary.

In conclusion, this study identified several morphometric characteristics associated with swimming efficiency. Leporinus elongatus and Prochilodus lineatus differed in several morphometric traits related to swimming performance, including the muscle ratio, caudal fin length ratio, caudal peduncle depth factor, length from snout to pectoral fin base ratio, and fineness ratio. Prochilodus lineatus has a higher body and greater muscle mass (MR). Nevertheless, $L$. elongatus has a thinner caudal peduncle and a greater fineness ratio, and its body is more streamlined than $P$. lineatus. Although both species show good swimming performance in the fish ladder, these characteristics may enable L. elongatus to apply greater power and propulsion, allowing it to reach a high swimming speed. The efficiency shown by this species is greater than that shown by $P$. lineatus. Morphometric ratios can be used to predict the swimming performance of $L$. elongatus and $P$. lineatus in conjunction with studies of swimming capacity (tests of prolonged and burst speed) to investigate possible differences in swimming speed/swimming capacity between the species. The predictive character of this type of approach would provide better accuracy. In addition, this approach would represent a significant contribution to help address the absence of basic information on the biology of Neotropical migratory fish species.

\section{Acknowledgements}

We thank Companhia Energética de São Paulo for financial and logistic support, Conselho Nacional de Desenvolvimento Científico e Tecnológico (CNPq) for Produtividade em Pesquisa-PQ (MCM) scholarship, and CAPES for Master's (AR) and Postdoctoral (EALK) scholarships.

\section{Literature Cited}

Aedo, J. R. 2008. Does Shape Predict Performance? An Analysis of Morphology and Swimming Performance in Great Basin Fishes. Unpublished Ph.D. Thesis. Faculty of Brigham Young University, Provo, Utah, 52p.

Agostinho, A. A., L. C. Gomes \& F. M. Pelicice. 2007. Ecologia e Manejo de Recursos Pesqueiros em Reservatórios do Brasil. Maringá, EDUEM, 512p.

Agostinho, A. A., L. C. Gomes, H. I. Suzuki \& H. F. Júlio Jr. 2003. Migratory fishes of the Upper Paraná River Basin Brazil. Pp. 19-89. In: Carolsfeld, J., B. Harvey, C. Ross \& A. Baer (Eds.). Migratory Fishes of South America: Biology, Fisheries and Conservation Status. Vitoria, World Bank, 372p.

Agostinho, A. A., F. M. Pelicice \& L. C. Gomes. 2008. Dams and the fish fauna of the Neotropical region: impacts and management related to diversity and fisheries. Brazilian Journal of Biology, 68: 1119-1132.

Aleev, Y. G. 1969. Function and Gross Morphology in Fish. Jerusalem, Program for Scientific Translations, 230p.

Bainbridge, R. 1960. Speed and stamina in three fish. Journal of Experimental Biology, 37: 129 -153.

Balon, E. K., S. S. Crawford \& A. Lelek. 1986. Fish communities of the Upper Danube River (Germany, Austria) prior to the new Rhein-Main-Donau connection. Environmental Biology of Fishes, 15: 243-271.

Bandyopadhyay, P.R., J. M. Castano, J. Q. Rice, R. B. Phillips, W. H. Nedderman \& W. K. Macy. 1997. Low-speed maneuvering and hydrodynamics of fish and small underwater vehicles. Journal of Fluids Engineering, 119: 136-144.

Beach, M. H. 1984. Fish pass design - criteria for the design and approval of fish passes and other structures to facilitate the passage of migratory fishes in rivers. Ministry of Agriculture, Fisheries and Food, Lowestoft, Fisheries Technical Report, 78: 1-46.

Beamish, F. W. H. 1978. Swimming capacity. Pp. 101-187. In: Hoar, W. S. \& D. J. Randall, (Eds.). Fish Physiology. New York: Academic Press. 
Blake, R. W. 1983. Functional design and burst-and-coast swimming in fishes. Canadian Journal of Zoology, 61: 2491-2494.

Breda, L., E. F. Oliveira \& E. Goulart. 2005. Ecomorfologia da locomoção de peixes com enfoque para espécies neotropicais. Acta Scientiarum: Biological Sciences, 27: 371-381.

Carneiro, S. C. 2003. Aspectos anatômicos relacionados à natação e à alimentação de nove espécies de peixes characiformes coletados nos rios Piracicaba e Mogi-Guaçu, Estado de São Paulo. Unpublished Ph.D. Thesis, Instituto de Biociências, UNESP, Rio Claro, 105p.

Castro-Santos, T. 2005. Optimal swim speeds for traversing velocity barriers: an analysis of volitional high-speed swimming behavior of migratory fishes. Journal of Experimental Biology, 208: 421-432.

Castro-Santos, T. \& A. Haro. 2010. Fish guidance and passage at barriers. Pp. 62-89. In: Fish locomotion: an eco-ethological perspective. Domenici, O. \& B.G. Kapoor (Eds.). Science Publisher, Enfield, New Hampshire, 534p.

Fisher, R. and Bellwood, D. R. 2003. Undisturbed swimming behaviour and nocturnal activity of coral reef fish larvae. Marine Ecology Progress Series, 263: 177-188.

Fisher, R., D. R. Bellwood \& S. D. Job. 2000. The development of swimming abilities in reef fish larvae. Marine Ecology Progress Series, 202: 163-173.

Fisher, R. \& J. D. Hogan. 2007. Morphological predictors of swimming speed: a case study of pre-settlement juvenile coral reef fishes. The Journal of Experimental Biology, 210: 2436-2443.

Gatz, Jr., A. J. 1979. Ecological morphology of freshwater stream fishes. Tulane Studies in Zoology and Botany, 21: 91-124.

Gerstner, C. L. 1999. Maneuverability of four species of coral-reef fish that differ in body and pectoral-fin morphology. Canadian Journal of Zoology, 77: 1102-1110.

Gosline, W. A. 1971. Functional Morphology and Classification of Teleostean Fishes. Honolulu: University Press of Hawaii, 208p.

Hammer, C. 1995. Fatigue and exercise tests with fish. Comparative Biochemistry and Physiology, 112: 1-20.

Jackson, D. A. 1993. Stopping rules in principal components analysis: a comparison of heuristical and statistical approaches. Ecology, 74: 2204-2214.

Keast, A. \& D. Webb. 1966. Mouth and body form relative to feeding ecology in the fish fauna of a small lake, Lake Opinion, Ontario. Journal of the Fisheries Research Board of Canada, 23: $1845-1874$.

Langerhans, R. B. \& D. N. Reznick. 2010. Ecology and evolution of swimming performance in fishes: predicting evolution with biomechanics. Pp. 200-248.In: Fish locomotion: an ecoethological perspective. Domenici, O. \& B.G. Kapoor (Eds.). Science Publisher, Enfield, New Hampshire. 534p.

Makrakis, S., L. C. Gomes, M. C. Makrakis, D. R. Fernandez \& C. S. Pavanelli. 2007b. The Canal da Piracema as a fishpass system. Neotropical Ichthyology, 5: 185-195.

Makrakis, S., M. C. Makrakis, R. L. Wagner, J. H. P. Dias \& L. C. Gomes, 2007a. Utilization of the fish ladder at the Engenheiro Sergio Motta Dam, Brazil, by long distance migrating potamodromous species. Neotropical Ichthyology, 5: 197-204.
Makrakis, M. C., L. E. Miranda, S. Makrakis, H. M. F. Junior, W. G. Morlis, J. H. P. Dias \& O. J. Garcia. 2012. Diversity in migratory patterns among Neotropical fishes in a highly regulated river basin. Journal of Fish Biology, 81: 866-881.

McCune, B. \& M. J. Mefford. 1999. PC-ORD: multivariate analysis of ecological data. Version 4.01. Oregon: MjM Software Design, 47p.

Nanami, A. 2007. Juvenile swimming performance of three fish species on an exposed sandy beach in Japan. Journal of Experimental Marine Biology and Ecology, 348: 1-10.

Ohlberger, J., G. Staaks \& F. Hölker. 2006. Swimming efficiency and the influence of morphology on swimming costs in fishes. Journal of Comparative Physiology B, 176: 17-25.

Plaut, I. 2001. Critical swimming speed: its ecological relevance. Comparative Biochemistry Physiology, 131: 41-50.

Pompeu, P., A. A. Agostinho \& F. M. Pelicice. 2011. Existing and future challenges: the concept of successful fish passage in South America. River Research and Applications DOI: 10.1002/rra.1557

Sambilay, V. C. Jr. 1990. Interrelationships between swimming speed, caudal fin aspect ratio and body length of fishes. Fishbyte, 8: 16-20.

Santos, H. de A., P. dos S. Pompeu \& C. B. Martinez. 2007. Swimming performance of the migratory Neotropical fish Leporinus reinhardti (Characiformes: Anostomidae). Neotropical Ichthyology, 5:139-146.

Santos, H. A, P. S. Pompeu, G. S. Vicentini, C. B. Martinez. 2008. Swimming performance of the freshwater neotropical fish: Pimelodus maculatus Lacepède, 1803. Brazilian Journal of Biology, 68: 433-439.

Scarnecchia, D. L. 1988. The importance of streamlining in influencing fish community structure in channelized and unchannelized reaches of a prairie stream. Regulated Rivers: Research and Management, 2: 155-166.

Triantafyllou, Michael S. \& Triantafyllou, George S. 1995. An efficient swimming machine. Scientific American, 272: 40-46.

Videler, J. J. 1993. Fish Swimming. London: Chapman \& Hall, 260p.

Videler, J. J. \& C. S. Wardle. 1991. Fish swimming stride by stride: speed limits and endurance. Reviews in Fish Biology and Fisheries, 1: 23-40.

Webb, P. W. 1975. Hydrodynamics and energetics of fish propulsion. Bulletin of the Fisheries Research Board of Canada, 190: 1-158.

Webb, P. W. 1984. Body form, locomotion and foraging in aquatic vertebrates. American Zoologist, 24: 107-120.

Webb, P. W. \& D. Weihs. 1986. Functional locomotor morphology of early life history stages of fishes. Transactions of the American Fisheries Society, 115: 115-127.

Winemiller, K. O. 1991. Ecomorphological diversification in lowland freshwater fish assemblages from five biotic regions. Ecological Monographs, 61: 343-365.

Submitted March 15, 2012 Accepted August 22, 2012 